\title{
Development and Application of an Integrated Curriculum Centered on Mathematics for Elderly Generations
}

\author{
Hyeung Ju Lee \\ Ministry of Education and Innovation, Kyonggi University, Republic of Korea
}

Purpose: To develop an education program based on adult learning principles and actual experiences of elderly generations to develop an integrated curriculum centered on Mathematics. Methods: Using a theme-based integrated curriculum design for a particular group of elderly learners $(n=4 \times 18)$, this study followed a sequence in program development: Assessing the needs, choosing a theme, studying a topic, writing a rationale, brainstorming, stating the learning objective, planning the project, establishing detailed activity plans, programming the learning time, and assessing the efficiency and the validity.

Results: Using our data analysis, core concepts were applied to everyday experiences of travel and cooking; the need to develop numeracy for elderly generations informed the development of unit objectives and learning outcomes within a Korean adult literacy curriculum. Implementation of the curriculum led to some improvement as evident from the pre- and post-results using the K-mmse; it was also possible for the elderly generations to engage in cooperative learning events and complement each other during the problem solving processes.

Conclusion: This study is significant in that it develops and applies the principles of Problem-based Learning (PBL) - an integrated curriculum design, use of real-life topics and consideration of the needs of the learner, in this case, elderly generations. As a learner-centered curriculum, it gave greater motivation to learners and made the mathematics subject relevant to their needs. It is necessary to consider the diversity across generations of learners and develop curricula in accordance with their needs.

Keywords: Integration Curriculum; Elderly generations; Mathematics; Curriculum; Thematic

\section{INTRODUCTION}

'Integration' implies 'the connection of things for the whole', or 'qualitative change to combine components into a new whole' (Myeoung, 2002). Over two decades ago the seventh curriculum for secondary education reestablished the concept of an integrated curriculum encouraging its management using activity-based topics rather than attempting integration across subjects (The Ministry of Education, 1997). However, integration is not evident within the environment of adult education in Korea. The National Institute for Lifelong Education was established as a part of aspirations for an approach to lifelong education or ongoing learning. Nevertheless, approaches to Korean education have not realized any principles for curriculum development for mature adults, although there are some positive developments.

Resources for elderly generations now center on 'The Adult Literacy Text (The National Institute for Lifelong Education, 2012)' emerging from a national project; the 2019 Adult Literacy Text will be soon published as a revised edition. Trial and error was a feature of the early stages of curriculum development suited to the principles of adult learning but curricula for the elderly

\footnotetext{
(C) Copyright 2019 International Society for Problem-Based Learning

(c) This is an Open Access article distributed under the terms of the Creative Commons Attribution Non-Commercial License (http://creativecommons.org/licenses/ by-nc/4.0/) which permits unrestricted non-commercial use, distribution, and reproduction in any medium, provided the original work is properly cited.
} 
generations of learners have made their mark through two development processes. Thus, our study on the development and application of an integrated curriculum is designed for elementary and secondary courses of adult literacy, providing suggestions for the methodology of curriculum development. The elementary course within these curricula focuses on adult literacy; when embedded within a secondary course, the same principles can be realized within a subject. The characteristics of this adult literacy curriculum for elderly generations in Korea are based on learning events reflecting everyday experiences of members of the elderly learners. The mathematical concepts underpinning the development of numeracy, should be considered a priority.

Curriculum design featuring the experiences of an elderly generations, and those of adults, overlap within a range of subject-based curricula; the overlap becomes intensified within topics and the incremental development of mathematical concepts. Some formal subjects can be seen as meaningless and time-wasting for the elderly. The ultimate goal for elderly learners is to improve their quality of life.

The learning needs of elderly generations are important as changes in society, especially around technologies, impact their lives. Elderly generations have led their lives independently. Their quality of life has become a hot issue in our society. Thus, we suggest the use of more learner-centered integrated curricula based on real life situations, reflecting everyday experiences. This integrated curriculum centered on mathematics emphasizes learning processes reflecting intuitive thinking, the development of cooperative teaching and learning among seniors to promote positive attitudes and integration of relevant information and knowledge in modern society.

Consideration of the hierarchical map of mathematical concepts was central to the education programs based on other real-life experiences of elderly learners. This study was designed to describe the outcomes of an integrated approach to development and application of relevant concepts centered on mathematics for elderly generations and how it applies in daily practice.

\section{THEORETICAL BACKGROUND}

\section{Theme-based Integrated Education}

'The Integrated Approach' has developed as a part of progressive education; it has been actively studied in Korea since 1990 (Kim, 2000). As early as 1979, Ingram reported that an integrated curriculum is significant for the following reasons that remain today.

First, learners can cultivate the ability to handle the extensive knowledge and information, that has increased these days.

The main ideas and basic principles underpinning integration are drawn from and reflected in a wide range of studies. Also, ideas from different realms of knowledge are linked in an organized way, promoting their relevance, accessibility, penetration and wholeness.

Second, the integrated approach makes learners follow their own learning process. The reflective thinking of Dewey (1933) and the discovery learning of Bruner (1961) emphasizes the learning process itself, asserting inquiry-based activities with topics rather than the acquisition of factual information. So, it can achieve a sense of balance within an individual as well as between the individual and the environment, developing evenly the cognitive and affective areas at the same time.

Third, integrated approaches have the function of learning how to cope with social problems. To solve various problems occurring in modern society, it is necessary that one should have the integrated knowledge applicable to many fields, not just knowledge of a specific field. In other words, the learning and the life experiences should not be isolated from Third, integrated approaches have the function of learning how to cope with social problems. To solve various problems occurring in modern society, it is necessary that one should have the integrated knowledge applicable to many fields, not just knowledge of a specific field. In other words, the learning and the life experiences should not be isolated from each other; school education for example should apply to everyday life.

Therefore, integrated educational content and processes are designed to link a lot of ideas systematically, helping with problem solving, organizing them in accordance with the development of learners, promoting their holistic growth, increasing cooperation among peers and thus maximizing the learning effect based on the interaction among the elements.

\section{Integrated Curriculum Centered on Mathematics for Elderly generations}

Research relevant to this study centered on mathematics education for elderly generations suggests it has application as follows: analysis of interactions between seniors in speed calculation, mathematics for development of thinking and gaming skills (Seo, 2007), approaches to development of programs to investigate mathematical characteristics relevant to the elderly in terms of cognitive and other affective areas (Lee, 2007;Joo, 2007;Lee, 2008) and analysis of 'calculation characteristics' in seniors (Choi, 2008).

Although few programs have been based on research, these are mainly composed of real-life topics and calculations. A mathematics literacy program was recently developed based on the experiences of elderly generations with mathematics education (Lee \& Ko, 2018). The experiences of elderly generations should have a central place in education considering their cognitive and affective needs. 


\section{Literacy Educational Processes for Adults}

The necessity for literacy educational processes for adults has been raised as an essential foundation to establish systems to certify qualifications, to provide literacy education for adults, to increase demand for learning materials, and to develop independent processes of education. The latter, suitable for adult learners, are differentiated from those for juvenile learners, especially in the field of literacy education. Thus, emerging from a focus on queries about demands for educational sites for literacy education for adults, consideration of the needs of professionals, developing textbooks for such education, thoughts of researchers, and advice from professionals working at their actual worksites, an essential system and content within a textbook was finalized (The National Institute for Lifelong Education, 2012).

The components for national literacy education for adults include suggestions for each step.

\section{Real-life Topic Selection}

In the Development Model of theme-based Integrated curricula (Frazee \& Rudnitski, 1995) the assessment process was as follows; (1) Assessing Needs $\rightarrow$ (2) Choosing a Theme in the Organization of Curriculum $\rightarrow$ (3) Selecting a Studying Topic for Each Subject $\rightarrow$ (4) Writing a Rationale for the Selected Topic and Concept $\rightarrow$ (5) Brainstorming $\rightarrow$ (6) Making a Statement for the Learning Objective $\rightarrow$ (7) Designing the Project $\rightarrow$ (8) Establishing the Detailed Activity Plan $\rightarrow$ (9) Planning the Learning Time $\rightarrow$ (10) Considering the Efficiency and Validity of Integrated Curriculum.

Our needs analysis suggested a program design to reflect cognitive and affective characteristics of elderly generations who might have graduated a long time ago or did not attend school at all. We tried to reflect excitement around their needs to learn mathematical concepts, as they thought these difficult to study and apply in many real-life situations. Their goal to learn about mathematical ideas was located around improvement in their quality of life. We selected life-based materials, that elderly generations are highly likely to develop an interest in and absorb because they are based on their experiences; we then applied these to concepts from the relevant mathematical text.

\section{METHODS}

Table 1 outlines the approach taken.

First, we investigated and then integrated the theories from the relevant literature to develop real-life education programs centered on mathematics using a 'theme-based integration' approach.

Second, we selected the developmental stages of theme-based education program based on the evidence from research before program development progressed.

Third, we considered the content validity of the education programs which we developed, with two onsite specialists and one educationalist; we then modified our plan according to feedback.

Fourth, we carried out the field study to search demonstrate effectiveness in application and demonstrate the worthiness of the chosen curriculum approach. The field study was carried out 18 times on a group of four elderly learners in the lifelong learning school located in Suwon, Korea.

\section{RESULTS}

\section{The development of an integration curricula centered on Mathematics for Elderly generations}

A. a) Selection of Educational Objectives and b) Learning Content

a) This study is designed as the developmental research of curriculum for elderly generation learners, comprehensively forming the real-life topics in the mathematics subject to improve the quality of life for learners.

b) the learning content used to develop centered on mathematics real-life curriculum is shown in Table 2.

B. The Content of 2007 Adult Literacy Education Course by Topic

The content of education programs, related to travel and cooking, are classified by subject, the relationship between them and those of 2007 Adult Literacy Curriculum.

Curriculum content was shown in Table. 2. The 2007 Adult

Table 1. Study approach

\begin{tabular}{|c|c|}
\hline Procedure & Contents \\
\hline \multirow[t]{2}{*}{ Analysis } & $\begin{array}{l}\text { Consideration of theme-based curriculum: Integration } \\
\text { Theory }\end{array}$ \\
\hline & $\downarrow$ \\
\hline Design & $\begin{array}{l}\text { Selection of Education Program Development Model } \\
\qquad \downarrow\end{array}$ \\
\hline \multirow[t]{3}{*}{ Development } & Education Program Topic Organization \\
\hline & Education Program Development \\
\hline & $\downarrow$ \\
\hline \multirow[t]{3}{*}{ Assessment } & Assessment of Education Program \\
\hline & -Expert Assessment of Content Validity \\
\hline & $\begin{array}{l}\text {-Learning Subject Assessment through Preliminary } \\
\text { Courses }\end{array}$ \\
\hline
\end{tabular}

Application Application of Integrated Curriculum Program for Adult Learners

${ }^{+}$Application of K-mmse: Korean version of Mini-Mental State Exam (Folstein et al., 1975; Lancu \& Olmer, 2006; Oh et al., 2010) 
Literacy Curriculum consists of Wish Tree (Volume1 Volume4), Learning Tree (Volume5 Volume8) and Wisdom Tree (Volume9 Volume12) by stages; however, we are presenting only Volumes 1 $\sim 12$ ' for convenience in this study.

a) The Topic of 'Travel'

The education program topic 'Travel', relates to 'Korean, Mathematics, and Society' in the 2007 Adult Literacy Curriculum, the major resource used. Specifically, the mathematics is based calculations, while the Korean and Society are related to their real life experiences; details are as follows in Table 3.

b) The Topic 'Cooking'

The topic cooking also relates to relevant material within the Learning Resources contained in other units: Korean,

Mathematics, English, Science and Society in the 2007 Adult Literacy Curriculum. Details are presented in Table 4.

\section{Systematization of Learning contents}

Subcategories for learning content were grouped and systematized; then, those concepts in each group were integrated through comprehensive integration processes to organize units. These are presented in the following flowcharts.

a) Integration of learning content in Figure 1.

b) The Composition of Units and Establishment of Education Objectives in Table 5.
Table 5. The establishment of education objective based on the comprehensive integration in travel

\begin{tabular}{|c|c|}
\hline Classification & Education Objectives \\
\hline \multicolumn{2}{|r|}{ 1. Summary } \\
\hline General Objective & To understand the overview of the travel unit. \\
\hline Detailed Objective & $\begin{array}{l}\text { To understand the learning content in the travel } \\
\text { unit. }\end{array}$ \\
\hline \multicolumn{2}{|r|}{ 2. Basic Knowledge } \\
\hline General Objective & To understand the basic knowledge for travel plans. \\
\hline \multirow[t]{8}{*}{ Detailed Objective } & To read and use calendars and timetables. \\
\hline & To make use of cellphone. \\
\hline & $\begin{array}{l}\text { To understand how to calculate the time and the } \\
\text { hour. }\end{array}$ \\
\hline & $\begin{array}{l}\text { To understand the concept and application of } \\
\text { tables and diagrams. }\end{array}$ \\
\hline & To understand the concept of distance and speed. \\
\hline & To understand the weather and tour maps. \\
\hline & To understand the concept of calculation. \\
\hline & To understand how to search via internet. \\
\hline \multicolumn{2}{|r|}{ 3. Application and Problem Solution } \\
\hline General Objective & $\begin{array}{l}\text { To enable the solution to problems through activity } \\
\text { tasks. }\end{array}$ \\
\hline \multirow[t]{5}{*}{ Detailed Objective } & To meet scheduling for meetings. \\
\hline & To confirm the weather and the location. \\
\hline & $\begin{array}{l}\text { To make reservations and scheduling (including } \\
\text { ticketing and accommodation) }\end{array}$ \\
\hline & To open an account and issue a cash card. \\
\hline & $\begin{array}{l}\text { To have the emergency measure (including } \\
\text { hospitals and pharmacies) in a travel destination. }\end{array}$ \\
\hline
\end{tabular}

Table 2. Reality-based stimulus material

\begin{tabular}{|c|c|c|c|}
\hline Classification of Real-Life Topics & Subcategories & Mathematical Activities & Learning Content \\
\hline \multirow{14}{*}{ I . Travel } & \multirow{3}{*}{ Budget planning } & Calculation & Calculation \\
\hline & & Calculator Application & Calculator \\
\hline & & Account Opening & Understanding of Interests and Calculation \\
\hline & \multirow[t]{4}{*}{ Weather Checking } & \multirow[t]{4}{*}{ Temperature $\left({ }^{\circ} \mathrm{C}\right)$ Unit } & Understanding of Symbols \\
\hline & & & Understanding Temperature \\
\hline & & & Understanding Fine Dust Unit \\
\hline & & & Application of Computers and Smartphones \\
\hline & \multirow[t]{4}{*}{ Scheduling using a table } & \multirow[t]{4}{*}{ Table Making } & Understanding Tables \\
\hline & & & Understanding Diagrams \\
\hline & & & Scheduling using tables and diagrams \\
\hline & & & Scheduling and Smartphones \\
\hline & \multirow[t]{3}{*}{ Ticket Preserving } & Calculation & Calculation \\
\hline & & \multirow[t]{2}{*}{ PC Application } & Calculator \\
\hline & & & Computer Application \\
\hline \multirow[t]{10}{*}{ II. Cooking } & \multirow[t]{2}{*}{ Basic Unit Diary } & \multirow[t]{2}{*}{ Volume and Weight Unit Diary } & Volume and Weight Unit Diary \\
\hline & & & Material Composition \\
\hline & \multirow[t]{4}{*}{ Nutrient Profile Diary } & \multirow[t]{2}{*}{ Pie Graph } & Pie Graph \\
\hline & & & Nutrient Composition Diary using a Pie Graph \\
\hline & & \multirow[t]{2}{*}{ Bar Graph } & Bar Graph Diary \\
\hline & & & Nutrient Comparison using a Bar Graph \\
\hline & \multirow{2}{*}{\multicolumn{2}{|c|}{ Understanding of Safety Regulations Electricity Use }} & Safety Cooking Utensil Manual \\
\hline & & & Using the Electronic Product Manual \\
\hline & & \multirow[t]{2}{*}{ Emergency Measure } & Minor Wound Treatment \\
\hline & & & Visiting a hospital/Calling an ambulance \\
\hline
\end{tabular}


Table 3. Travel: Content from 2007 Adult Literacy Curriculum

\begin{tabular}{|c|c|c|c|}
\hline Subject & Title & Contents & $\begin{array}{l}2007 \text { Adult Literacy } \\
\text { Curriculum }\end{array}$ \\
\hline Korean & Going on a Visit & To go on a visit with friends. & Volume 2 Chapter 13 \\
\hline Mathematics & Calendar & To make and read a yearly or a weekly calendar. & Volume 2 Chapter 17 \\
\hline Mathematics & Watch & To read the time and the digital watch. & Volume 3 Chapter 17 \\
\hline Korean & Sign & $\begin{array}{l}\text { To read and write the names of various signs and then name } \\
\text { them in accordance with attached pictures. }\end{array}$ & Volume 3 Chapter 15 \\
\hline Mathematics & Addition and Subtraction & $\begin{array}{l}\text { To understand the symbols of 'plus (+)' and 'minus (-)'. } \\
\text { To read and write the addition and subtraction of one-digit } \\
\text { numbers. }\end{array}$ & Volume 4 Chapter 18 \\
\hline Korean & Taking a Bus & To understand the types and usage of means of transportations. & Volume 5 Chapter 10 \\
\hline Korean & Train Trip & To read travel notices and make use of their information. & Volume 5 Chapter 11 \\
\hline Korean & Weather Cast & To read written details on the weather. & Volume 5 Chapter 12 \\
\hline Mathematics & Addition 1 & To add one-digit numbers with 'carrying'. & Volume 5 Chapter 26 \\
\hline Korean & Notification & To read and understand various notices. & Volume 5 Chapter 15 \\
\hline Korean & Country & To understand each, Do(province) in Korea. & Volume 5 Chapter 24 \\
\hline Korean & City's Name & To understand the names and locations of Korean main cities. & Volume 5 Chapter 25 \\
\hline Mathematics & Addition 2 & To add two-digit numbers to one-digit numbers. & Volume 5 Chapter 27 \\
\hline Mathematics & Addition of two-digit Numbers & To add two-digit numbers with 'carrying'. & Volume 6 Chapter 26 \\
\hline Mathematics & Subtraction 1 & To subtract numbers with 'borrowing'. & Volume 6 Chapter 27 \\
\hline Korean & Cellphone Etiquette & Cellphone Etiquette (in public spaces) & Volume 6 Chapter 19 \\
\hline Mathematics & Subtraction 2 & To subtract two-digit numbers with 'borrowing'. & Volume 6 Chapter 28 \\
\hline Korean & Advertisement in our daily life & To understand the meaning in advertisements. & Volume 7 Chapter 6 \\
\hline Mathematics & Figure & To distinguish triangles and quadrangles. & Volume 7 Chapter 27 \\
\hline Korean & Today's News & $\begin{array}{l}\text { To grasp the content of news written in accordance with five w's } \\
\text { and one } h \text {. }\end{array}$ & Volume 7 Chapter 15 \\
\hline Korean & Five W's and One H & $\begin{array}{l}\text { To read notices and understand them considering five w's and } \\
\text { one } h \text {. }\end{array}$ & Volume 7 Chapter 16 \\
\hline Mathematics & Time and Hour & To read the hourly train timetable and calculate time. & Volume 7 Chapter 26 \\
\hline Mathematics & Multiplication 1 & $\begin{array}{l}\text { To learn the principle of multiplication and then memorize the } \\
\text { multiplication table (two times to five times). }\end{array}$ & $\begin{array}{l}\text { Learning Tree } \\
\text { Volume } 3 \text { Chapter } 28\end{array}$ \\
\hline Mathematics & Multiplication 2 & $\begin{array}{l}\text { To learn the principle of multiplication and then memorize the } \\
\text { multiplication table (six times to nine times). }\end{array}$ & Volume 7 Chapter 29 \\
\hline Korean & Visiting a Bank & To read and write based on the experience of visiting a bank. & Volume 8 Chapter 4 \\
\hline Mathematics & Length & To understand the concept and unit of length. & Volume 8 Chapter 26 \\
\hline Korean & Environmental Protection & To understand and practice environmental protections. & Volume 8 Chapter 12 \\
\hline Mathematics & Weight & To understand the concept and unit of weight. & Volume 8 Chapter 27 \\
\hline Korean & Public Etiquette & To understand and practice public etiquette. & Volume 8 Chapter 19 \\
\hline Mathematics & Division & To understand the division and then divide one-digit numbers. & Volume 8 Chapter 28 \\
\hline Society & Tour Map & To read and understand tour notices and maps. & Volume 9 Chapter 7 \\
\hline Mathematics & How to Use a Calculator & To solve calculation problems using a calculator. & Volume 9 Chapter 24 \\
\hline Mathematics & Addition of Three-digit Numbers & To add three-digit numbers. & Volume 9 Chapter 25 \\
\hline Mathematics & $\begin{array}{l}\text { Subtraction of Three-digit } \\
\text { Numbers }\end{array}$ & To subtract three-digit numbers. & Volume 9 Chapter 26 \\
\hline Mathematics & $\begin{array}{l}\text { Multiplication of Two-digit } \\
\text { Numbers. }\end{array}$ & To multiply two-digit numbers. & Volume 10 Chapter 24 \\
\hline Society & Economy and Life & To understand about markets and the economy. & Volume 10 Chapter 19 \\
\hline Society & Climate & To understand the climate of other countries and ours. & Volume 10 Chapter 23 \\
\hline Mathematics & Distance and Speed & $\begin{array}{l}\text { To understand the concept of distance and speed and their } \\
\text { relationship. }\end{array}$ & Volume 11 Chapter 25 \\
\hline
\end{tabular}


Table 4. Cooking: Content from 2007 Adult Literacy Curriculum

\begin{tabular}{|c|c|c|c|}
\hline Subject & Title & Contents & $\begin{array}{l}2007 \text { Adult Literacy } \\
\text { Curriculum }\end{array}$ \\
\hline Korean & A-frame and Stews & To distinguish 'ス', ' $₫$ ' and '大'. & Volume 4 Chapter 4 \\
\hline Korean & Pickling cabbage & To distinguish homonyms. & Volume 5 Chapter 3 \\
\hline Korean & Selection of Hospital & To understand information on types and treatment processes of hospitals & Volume 5 Chapter 8 \\
\hline Korean & Caution against Fire & To understand the telephone number necessary on emergency. & Volume 5 Chapter 21 \\
\hline Korean & Saving Electricity & Sentence completion and the consumption of electricity. & Volume 6 Chapter 6 \\
\hline Korean & Spacing Class & Understand spacing for reading and writing. & Volume 7 Chapter 1 \\
\hline Korean & New Year's Day in Different Countries & To compare New Year's Days in different countries. & Volume 8 Chapter 8 \\
\hline Mathematics & Weight & To understand concepts and units of weight. & Volume 8 Chapter 27 \\
\hline English & Alphabet Song & To read and write alphabet: Upper and lower cases. & Volume 9 Chapter 4 \\
\hline Science & State of Matter & The State and Change of Matter. & Volume 9 Chapter 19 \\
\hline Science & Nutrients of Food & To understand types of nutrients, nutrient-rich foods and avitaminosis. & Volume 10 Chapter 4 \\
\hline Korean & My Recipe & My Recipe for explanations to others. & Volume 10 Chapter 11 \\
\hline Mathematics & Fraction & To understand the concept of fraction. & Volume 10 Chapter 25 \\
\hline Mathematics & Comparing the size of fractions & To compare the size of fractions. & Volume 10 Chapter 26 \\
\hline Society & Economy and Life & To understand the market and the economy. & Volume 10 Chapter 19 \\
\hline Korean & Caution against Fire & Fire Prevention and Measure. & Volume 10 Chapter 22 \\
\hline Mathematics & Addition and Subtraction of Fraction & To add and subtract fractions. & Volume 10 Chapter 27 \\
\hline Mathematics & Decimal & To understand the concept of decimal. & Volume 11 Chapter 24 \\
\hline Science & Healthy Dietary Life & To understand dietary elements for healthy life. & Volume 11 Chapter 21 \\
\hline Mathematics & Quantity Unit & To read and understand units of quantity. & Volume 12 Chapter 24 \\
\hline Mathematics & Understanding of Percentage (\%) & To understand and calculate percentages. & Volume 12 Chapter 25 \\
\hline Mathematics & Graph & To understand and interpret graphs. & Volume 12 Chapter 26 \\
\hline
\end{tabular}

Table 6. The establishment of education objective based on the comprehensive integration in cooking

\begin{tabular}{|c|c|}
\hline Classification & Education Objectives \\
\hline \multicolumn{2}{|r|}{ 1. Summary } \\
\hline General Objective & To understand the overview of cooking units. \\
\hline Detailed Objective & To understand the learning content in cooking unit. \\
\hline \multicolumn{2}{|c|}{ 2. Basic Knowledge } \\
\hline General Objective & To understand basic knowledge of food. \\
\hline \multirow[t]{9}{*}{ Detailed Objective } & To understand the concept of weight and volume. \\
\hline & To understand the unit of weight and volume. \\
\hline & To understand fractions, decimals and percentages. \\
\hline & To understand graph. \\
\hline & To understand the concept of matter. \\
\hline & To understand nutrients in foods. \\
\hline & $\begin{array}{l}\text { To understand the composition of healthy dietary } \\
\text { life. }\end{array}$ \\
\hline & $\begin{array}{l}\text { To understand the safety regulations of home } \\
\text { appliances. }\end{array}$ \\
\hline & To understand fire-fighting prevention measures \\
\hline \multicolumn{2}{|r|}{ 3. Application and Problem Solution } \\
\hline General Objective & $\begin{array}{l}\text { To enable solutions through problem through } \\
\text { activity tasks. }\end{array}$ \\
\hline \multirow[t]{4}{*}{ Detailed Objective } & To select foods and cooking processes. \\
\hline & To make a recipe. \\
\hline & To compose the nutrients of food. \\
\hline & To understand the emergency measures. \\
\hline
\end{tabular}

The following flowchart elaborates on how the we established the composition of learning content for the travel unit and the establishment of education objective based on the comprehensive integration processes.

The composition of learning content for cooking unit and the establishment of education objective based on the comprehensive integration in Table 6.

\section{The Assessment of an Integrated Curriculum centered on Mathematics for Elderly generations}

A. The Expert Assessment of Content Validity.

The experts' assessment process was designed to see that the content and level of theme-based integration curriculum were developed with consideration of the learners as follows: According to the opinion of experts, the program provides content which meets the education objectives, to apply in the field study for elderly learners, and thus achieves its development purpose. In particular, they said that it includes those highly accessible concepts underpinning the interests of learners. However, they pointed out that elderly learners spend a lot of time fully understanding in-depth areas of study. Also, there were some opinions expressed that around the question of program design that leads to personal problem solving i.e. self-direction in learning. They 


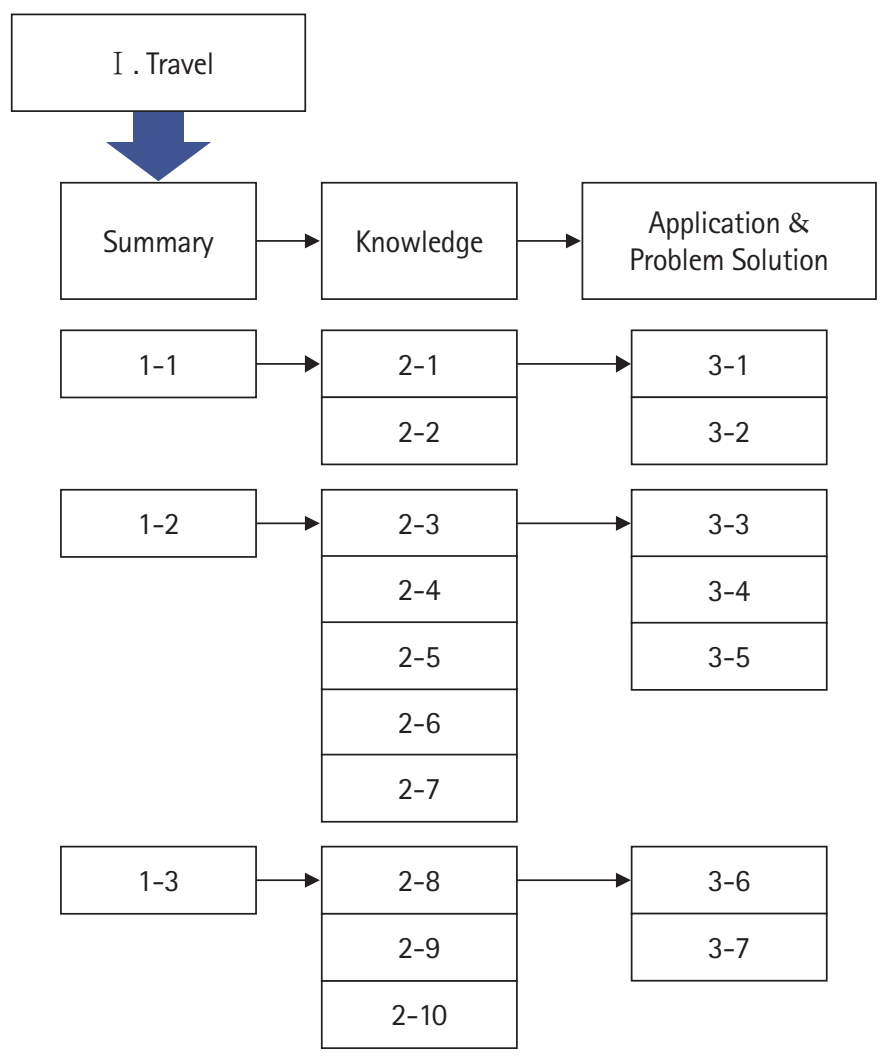

\section{Summary \\ 1-1 Weather and Scheduling \\ 1-2 Plan \\ 1-3 Establishment of Dues}

2. Basic Knowledge

2-1 Calendar

2-2 Watch

2-3 Cellphone

2-4 Hour and Time

2-5 Table and Diagram

2-6 Distance and Speed

2-7 Tour Map and Weather

2-8 Calculation Concept

2-9 Calculation

2-10 Internet Searching

3. Application and Problem Solution

3-1 Scheduling

3-2 Weather

3-3 Location using Tour Maps

3-4 Searching (including tourist attractions, accommodations and famous restaurants)

3-5 Reservation and Scheduling

(including ticketing and accommodation)

3-6 Account Opening and Cash Card Issuing for Dues.

3-7 Emergency Measure (including hospitals and pharmacies)

\section{Summary}

1-1 Basic Knowledge for Foods

1-2 Nutrient and Dietary Life

1-3 Home Appliance Manual
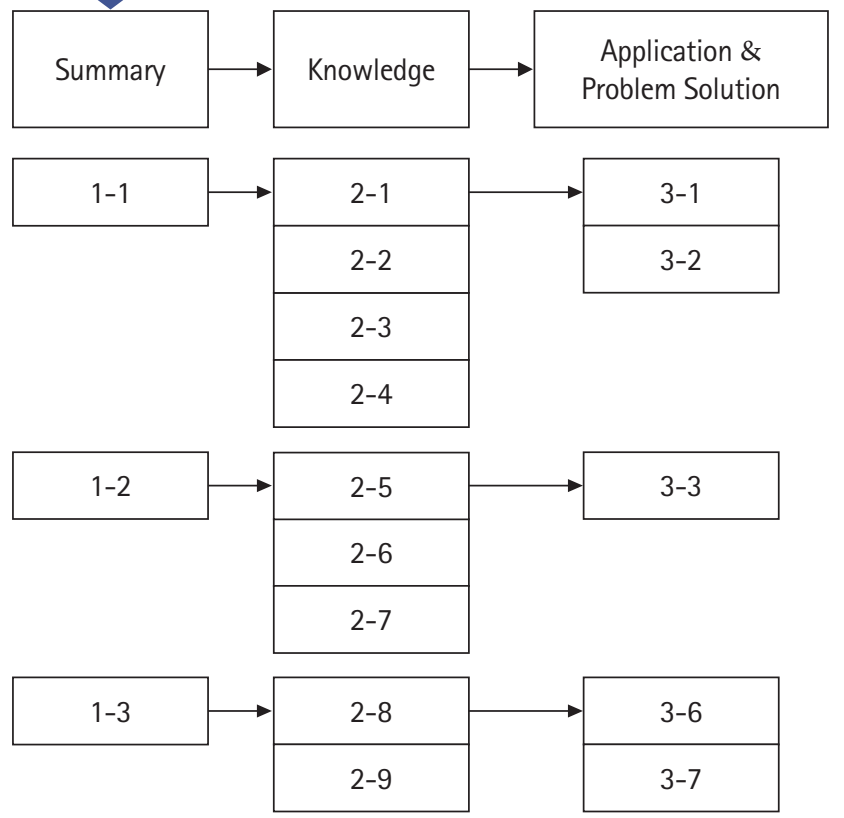

Figure1. Integration of learning content

\section{Basic Knowledge}

2-1 Concept of Weight and Volume

2-2 Unit of Weight and Volume

2-3 Fraction, Decimal and Percentage

2-4 Graph

2-5 State of Matter

2-6 Food Nutrient

2-7 Healthy Dietary Life

2-8 Safety Regulations for Home Appliances

2-9 Fire and Accident Manual

3. Application and Problem Solution

3-1 Selection of Foods and Ingredients

3-2 Food Recipe Composition

3-3 Food Nutrient Composition

3-4 Emergency Measure 
suggested that learners might need the guidance of their instructors during the course e.g. using a computer.

Based on the results of above expert assessment, we modified units after considering each piece of feedback. This newly developed program was modified again through many preliminary course implementation processes.

\section{B. The Field Study}

When the proposed program was applied in actual classes, elderly learners became highly interested unlike the case where they originally learned about subjects centered on mathematics. Also, these learners reported that they could recognize the need for mathematics given their participation in the program; learners expressed opinions that the program was valuable, as it allowed them to use a calculator on complicated mathematical problems. However, some respondents said they were not confident with mathematics i.e. when using a computer or learning the difficult terms for ingredients during the cooking unit.

As a result of field study feedback, we adjusted the difficulty of computer skills learning activities.

\section{Application of Curricula for Elderly Learners.}

We implemented this program with four elderly generation learners 18 times; dividing them into groups of two, they participated into group learning processes twice a week. We used the K-mmse (Korean version of Mini-Mental State Exam) tool (Folstein et al., 1975; Lancu \& Olmer, 2006; Oh et al., 2010) before and after the course so that we could detect change. Their results were as follows in Table 7.

Table 7. K-mmse test result according to curriculum application

\begin{tabular}{lccc}
\hline Learner & Pre & Post & Difference \\
\hline Learner A & 25 & 29 & +4 \\
Learner B & 23 & 26 & +3 \\
Learner C & 17 & 21 & +4 \\
Learner D & 21 & 23 & +2 \\
\hline
\end{tabular}

The following are records of conversations of learners during the course; these show how they solved their problems. In the following situation, Learners A and B were paired to interpret the graph during the travel unit; they were expected to identify from the graph, the second preferences for the site where travelers wanted to go. This question is designed to find that they can read and interpret the graph. Learner B understood exactly the situation; he correctly answered the Palace Museum. Learner A tried to convince him that the tourist attraction is the place they want. However, Learner B again explained the situation to Learner A, but they could not resolve their differences. So, the teacher intervened to help them find the relevant data.

Learner B: Where is the place, where the members want to go most second, in this graph? this is the Palace Museum.

Learner A: No. maybe this is the tourist attraction.

Learner B: The Palace Museum. Sister, look at here. You should see it (pointing at the question). The tourist attraction is here (Pointing at the neighboring bar graph).

Learner B: Um? The place they want to go to. The palace museum.

Learner A: So, they took a bath in the place where they wanted to go most second, and they may hope to go to the tourist attraction.

Learner B: Hey, I already selected the palace (museum) as the second place?

Learner A: I think it is for the tourist attraction? This is the second most visited place...

Teacher: Please consider the height of each bar graph. Can it be counted using this table?

Learner A: (Pointing at the graph by the finger) Here? here? the second most... ah... it is the museum.

In the following case Learners $\mathrm{C}$ and $\mathrm{D}$ were paired to interpret the graph during the cooking unit. The question was about the ratio of each ingredient (including fat and protein) in the pie graph. Learner D understood the nutrient was carbohydrate, accounting for 68 percent in the pie graph. Learner $\mathrm{C}$ understood that protein accounted for 9 percent. The following conversation shows how they discussed the question, encouraging each other.

Learner C: um... others... (read again more carefully for a while) Other fats, protein, water. So, others, fats, protein and water are 2 percent, 3 percent, 9 percent and 18 percent, respectively. Isn't the total 100? Learner D: Yes, you're right. Haven't you learned pro (the abbreviation of percentage) carbohydrate accounts for 68 percent.

Learner C: Carbohydrate accounts for 68 percent. So, you mean that all should add up. I learnt gram (g) as well.

Learner C: 68\%. Write the most ratio here. Read... (read the question carefully) 'Write the most ingredient in this food.' So, we write 'carbohydrate' here.

Learner C: Do I write 68 only?

Learner D: You should write pro (percentage) also. (Alas) I haven't known these until now.

Learner C: It's not too late. I do this thing! (Laugh)

\section{CONCLUSIONS AND RECOMMENDATIONS}

This study was designed to develop an integrated curriculum centered on mathematics for elderly generations, using real-life topics based on the experiences of the elderly learners. We analyzed the content of many different subjects in Korean adult literacy curricula to develop an integrated curriculum. Tests for content validity were undertaken by three experts including two onsite specialists and one subject-educationalist. Curricula were modified 
immediately using the evaluation of learners. Learners were reported to intuitively understand the mathematical concepts, including their real-life elements used as topics; clearly, motivation enhanced the understanding of mathematical concepts.

It is evident that ongoing education is essential in seniors and members of the elderly generations if improvements in their quality of life is to be achieved. Therefore, the establishment of appreciation of educational content and processes and instructor expertise on the characteristics of learners is important if educational outcomes can be optimized for learners. Consideration of their varied experiences and levels of cognitive and physical functions will also impact management of social situations. Like all learners, the individual needs of those of elderly generations should be central to curriculum design and the development of learning activities.

\section{ACKNOWLEDGEMENTS}

This paper was supported by funding from the Halla Newcastle PBL Education and Research Center. The authors thank Professor Margaret McMillan, The University of Newcastle, for her guidance in preparing this paper for publication.

\section{REFERENCES}

Bruner, J. S. (1961). The act of discovery. Harvard Educational Review, 31(1), 21-32.

Choi, J. H. (2008). A Case Study of Learning Characteristics in the Education of the Elderly generations. Unpublished master's thesis, Ajou University, Gyeonggi-do, Korea.

Dewey, J. (1933). How We Think. Boston DC: Health and Co.

Folstein, M. F., Folstein, S. E., \& McHugh, P. R. (1975). Mini-Mental state: a practical method for grading the cognitive state of patients for the clinician. Journal of Psychiatry Res, 12(3), 189-98.

Frazee, B. M., \& Rudnitski, R. A. (1995). Integrated teaching methods: Theory, classroom applications, and field-based con- nections. Albany NY: Delmar Publishers.

Ingram, J. B. (1979). Curriculum integration and lifelong education. NY: Pergamon Press.

Joo, K. O. (2007). Development of game mathematics material as the elderly educations. Unpublished master's thesis, Ajou University, Gyeonggi-do, Korea.

Kim, J. B. (2000). An integrated approach to Curriculum. Seoul: Kyo-yook-book.

Lancu, I., \& Olmer, A. (2006). The minimental state examination: an up-to-date review. Harefuah, 145(9), 687-90.

Lee, S. K. (2007). The Development and Realization of Speed Gaming Mathematics for the Elderly. Unpublished master's thesis, Ajou University, Gyeonggi-do, Korea.

Lee, G. H. (2008). The Development of materials for Mathematical Activity to Improve the Recognition of the Elderly generations. Unpublished master's thesis, Ajou University, Gyeonggi-do, Korea.

Lee, H. J., \& Ko, H. K. (2018). A Study for Numeracy program Development of the elderly generation. Communications of Mathematical Education, 32(4), 519-536.

Myeoung, J. H. (2002). Unit development through theme-based integration in elementary social studies. Unpublished master's thesis, Gongju National University of Education, Korea.

Oh, E. A., Kang, Y. W., Shin, J. H., \& Yeon, B. K. (2010). A Validity Study of K-MMSE as a Screening Test for Dementia: Comparison Against a Comprehensive Neuropsychological Evaluation. Dementia and Neurocognitive Disorders, 9, 8-12.

Seo, H. J. (2007). A Case Study on the Elderly generations Classroom as part of Mathematical Education: An Analysis of Class Case through Interaction. Unpublished master's thesis, Ajou University, Gyeonggi-do, Korea.

The Ministry of Education. (1997). Description of elementary school curriculum. 1. General theory, Korean, Math. Seoul: Korea authorized and approved textbook.

The National Institute for Lifelong Education. (2012). Literacy Textbooks for Adults in Korea. Seoul: Mirae N. 